\title{
Waiting for Miracles: The Commercialization of Urban Water Services in Zambia
}

\section{Hulya Dagdeviren}

\begin{abstract}
This article focuses on the commercialization of urban water services in Zambia. It aims to demonstrate the tension between cost recovery and service extension when water sector reforms combine investment cuts with price increases. It is argued that in low-income economies where infrastructure limitations are serious and poverty is widespread, heavy reliance on 'tariff rationalization' with low levels of investment can lead to reduced access to water and render water charges unaffordable. Reforms to public services can prove futile in the absence of upfront resources for investment in the restoration and extension of the existing infrastructure. In many ways, Zambia typifies other low-income economies; this study thus offers useful lessons for them.
\end{abstract}

(First unnumbered footnote)

The original research and fieldwork for this article was carried out for a project funded by the United Nations Development Programme (UNDP). Thanks are due to Terry McKinley, Michael Soko and other staff of the UNDP Zambia office. The resources provided by Oswald Chanda, Kasonge Lumba and Kelvin Chitumbo of the National Water and Sanitation Council are greatly appreciated. I am also grateful to Kate Bayliss, Ben Fine, Keith Salmon and two anonymous referees who provided extensive comments on early drafts. 


\section{INTRODUCTION}

Halving the estimated 1.1 billion people without access to safe drinking water by 2015 is one of the Millennium Development Goals. At the current rate of progress it is unlikely that this target will be achieved in many parts of the developing world. According to the most recent Human Development Report, 2040 is a more likely date for this goal to be reached in Africa unless there is accelerated investment in the sector (UNDP, 2006).

A water sector crisis in Africa followed the recessionary conditions of the 1970s, when many suppliers found themselves in a financial vicious circle caused by a decline in government funding of capital expenditure, low tariffs, low billing, low revenue collections and increasing demand for water (Shirley, 2002). The neoliberal solution to problems in the water sector has been privatization. However, the experiments of more than a decade have shown that privatization of water services was a poor policy prescription, involving 'spectacular failures' in the words of UNDP (2006: 92). Problems have been associated with the difficulty of establishing competitive market structures (Estache et al., 2005; Kessides, 2004; Kirkpatrick et al., 2006), ineffectiveness of regulation in the presence of information asymmetries and incomplete contracts (Martimort, 2006), and negative welfare effects (Bayliss, 2003; Dagdeviren, 2006; Ugaz and Price, 2003). Over the years, the confidence of the public in the benefits of utility privatization and that of the private sector in the profitability of developing country utilities, especially water, have dwindled. Private investment in infrastructure projects has declined and many existing private operations have been subject to re-negotiation (Hall and Lobina, 2004; Harris, 2003).

In many low-income economies, investment needs in the water sector are colossal and the affordability of rising water tariffs is usually a problem. Hence, neither full privatization, nor public-private partnerships which do not involve substantial transfers from the public sector, are attractive for the multinational investors who dominate the water sector (Kirkpatrick and Parker, 2006; Lobina, 2005). As a result, the commercialization of services under public corporations has become the de facto policy in many countries such as Zambia. Indeed, current trends in the low-income economies are increasingly being determined by corporatization of existing public suppliers and commercialization of services (Estache et al., 2005; Prasad, 2006; 
Smith, 2006). This is sometimes used as an intermediate step before further privatization, as in the case of water supply in Lusaka.

The stated aims of commercialization in the water sector are cost recovery and improved access to water (McDonald, 2002). Apart from organizational changes (the creation of commercial utilities and their separation from the municipal authorities, introduction of regulatory mechanisms, etc.), under the new framework suppliers are required to improve their billing and revenue collection rates, reduce overstaffing and rationalize tariffs in an effort to achieve full cost recovery. In practice, in low-income countries enduring a prolonged period of economic austerity, the commercialization of water services has been an instrument for governments to relinquish their responsibility for funding investments in network expansion. While, in general, water sector reforms for improving efficiency, service quality and access are welcome, heavy reliance on tariff rationalization without paying much attention to investment and maintenance needs could be a serious problem.

This article aims to demonstrate that cost recovery through corporatization of suppliers and commercialization of services is likely to be unattainable under conditions of serious infrastructure limitations (such as a small and ageing network) when reforms are based on tariff rationalization and cuts in capital expenditure. This strategy creates a sequence of problems such as unaffordable water tariffs, reduced access to water and greater inefficiency. It is argued that up-front investment for the renewal and extension of the existing infrastructure is likely to be more effective in reducing the costs of maintenance and 'unaccounted for water' and making better use of economies of scale in the sector.

The discussion is based on, and supported by, a case study of urban water services in Zambia. The characteristics of Zambia and its water sector in many ways typify those of other low-income economies with, for example, high levels of poverty, limited access to water and a crumbling water network in the urban centres. Hence, its experience with commercialization and the lessons associated with it should be highly relevant elsewhere. After setting out the background and context of water sector reforms in Zambia, the article assesses the impact of water sector commercialization in terms of current cost-recovery levels by the ten urban water utilities operating in Zambia, the affordability of water charges, and the access rates to urban water supply. The outcomes are then evaluated with an emphasis on the need for prioritizing investment in the sector.

Development and Change, Vol. 39, Issue 1, January 2008 


\section{COMMERCIALIZATION OF PUBLIC WATER SERVICES IN ZAMBIA}

Zambia was a middle-income country at independence in 1964. Its fortunes changed drastically in the 1970s with the decline in the terms of trade of its principal output and export, copper. Since then, economic decline has affected every development parameter. Per capita incomes fell from US\$ 752 in 1965 to US\$ 351 in 2002. It is one of the most indebted countries in sub-Saharan Africa. Life expectancy droppped from fifty-one years in 1982 to just thirty-seven years in 2002, the lowest in Africa (World Bank, 2005). According to the Living Conditions and Monitoring Survey (LCMS) 2002-03, the country suffers from high levels of poverty and inequality with a headcount ratio of 68 per cent and Gini coefficient of 0.61 (Central Statistical Office, 2004).

Prior to the 1990s, municipal authorities were responsible for the operation and delivery of urban water and sanitation. The infrastructure was owned, maintained and extended by the central government. A different arrangement existed in the Copperbelt where Zambia Consolidated Copper Mines owned and operated the water network and supplied water to the mines, its employees and other residents in the mine townships. Water tariffs in all the urban centres of Zambia were heavily subsidized. Charges were paid as part of rents and were mostly unnoticed by users.

Economic decline took its toll on essential services, including water supply. The crisis in the sector deepened when financial bottlenecks facing the municipal operators - which arose from low billing and low revenue collection - were accompanied by cuts in central government funding following a general economic deterioration after the 1970s. This meant that access to water by the urban population could not be extended; in fact, it has declined slightly since the early 1990s. As discussed below the small size of the system and the ageing infrastructure in many urban centres have inflated the unit cost of accounted water, partly through rising 'unaccounted for' water rates over time. The policy of cost recovery under such conditions has had negative implications for water tariffs, as reflected in Table A1 in the Appendix.

Reform initiatives in the sector were considered as early as 1976 and continued into the 1980s. Most notable were the reforms aimed at commercialization and Development and Change, Vol. 39, Issue 1, January 2008 
attempts at privatization: pilot schemes started with the water supply and sanitation system in Lusaka in 1989 and in Eastern Province in 1992, and similar programmes followed in other provinces after 2000. The process involved a number of legislative and institutional changes from 1992 to 2000, including the establishment of a regulatory authority, the National Water and Sanitation Council (NWASCO). The core objective of commercialization has been to achieve cost recovery in water services. While water companies have been required to improve their operational efficiency (billing and collections) for this purpose, the emphasis of the reform process which started in 1992 has been on increasing tariffs.

As of November 2006, there were ten commercial water and sanitation companies (WSCs) in the major urban centres of Zambia, which contain 90 per cent of the country's urban population. ${ }^{1}$ Each WSC has a regional or provincial monopoly in water supply and distribution. As municipal governments are the sole shareholders in WSCs, they appoint the Boards of Directors, which recruit and oversee the performance of senior management of the companies.

Privatization, although permitted by the 1997 water and sanitation act, did not feature in the process of restructuring water services; except for a management contract awarded in the mining towns of the Copperbelt, the most financially viable service area. The implementation of the contract was only possible with a World Bank loan to the government to cover various expenses, including management fees and network rehabilitation. ${ }^{2}$ Even then, the contract was terminated in 2005 on the grounds that the privatized management did not perform any better than publicly owned utilities. The service responsibility was transferred to another public utility in the province, Nkana WSC.

One of the positive developments in the sector since the inception of the reforms is the role played by the regulatory body, NWASCO (World Bank, 2004). More information is now publicly available about the operation and performance of commercial WSCs than about municipal providers and water schemes developed by the NGOs, which were not subject to independent regulation until 2005. Since then, NGO schemes are also covered in the regulator's annual reports, which detail companies’ progress in performance and identify their weaknesses. These annual

\footnotetext{
${ }^{1}$ As of 2006, a further twenty-two municipal centres were yet to organize their water and sanitation services along commercial lines.

${ }^{2}$ The contract was awarded to AHC MMS, a local subsidiary of SAUR.
}

Development and Change, Vol. 39, Issue 1, January 2008 
reports seem to have fostered 'yardstick competition' and brought some dynamism into the sector. The availability of information on comparative performance seems to be forcing companies to take remedial actions and to improve their service delivery. Independent water-watch groups are also emerging to raise the awareness of users about their rights and develop a capacity for dealing with concerns and complaints about water companies.

IMPACTS OF COMMERCIALIZATION OF URBAN WATER SERVICES IN ZAMBIA

\section{Cost Recovery in Commercial Public Utilities}

The interpretation of the success or failure of the commercialization process in the water sector in terms of cost recovery ${ }^{3}$ depends on the method of assessment and indicators used. For example, comparisons between the commercial public utilities and local authority suppliers indicate that the performance of the latter group is inferior in terms of revenue collection and cost recovery (NWASCO, 2006). This is confirmed by MLGH (2004), which clearly shows that the public commercial utilities generate more revenues and achieve better cost recovery. Comparisons amongst the ten commercial utilities show great variation in cost recovery levels (Table 1). Some, like Kafubu WSC, are much closer to recovering their costs, while others, like Northwestern WSC, lag well behind.

Short-term comparisons yield different results than long-term ones. For example, focusing on performance from 2000 onwards — when most of the commercial utilities were established — would indicate that there have been improvements on some fronts such as bill collection and cost recovery (Table 1) and metering (NWASCO, 2005). Yet, even with a short-term focus, it is clear that most utility companies were far from achieving full recovery of their operational and maintenance costs after 2001 (Table 1) despite the fact that water tariffs have increased significantly in real terms. For example, fixed monthly charges for low-cost

\footnotetext{
${ }^{3}$ In this article, cost recovery is measured as the ratio of collections to the operational and maintenance costs.
}

Development and Change, Vol. 39, Issue 1, January 2008 
housing categories, which apply to the majority of the urban population in Zambia, have increased two to seven-fold in real terms since 1990 (see Table 2).

Table 1. Selected Indicators of Cost Recovery (\%)

\begin{tabular}{|c|c|c|c|c|c|c|c|c|}
\hline \multirow{2}{*}{$\begin{array}{l}\text { Water } \\
\text { Companies }\end{array}$} & \multicolumn{2}{|c|}{$\begin{array}{l}\text { Collection to } \\
\text { billing ratio }\end{array}$} & \multicolumn{2}{|c|}{$\begin{array}{c}\text { Collection to } \\
\text { cost ratio }^{\mathrm{a}}\end{array}$} & \multicolumn{2}{|c|}{$\begin{array}{l}\text { Unaccounted } \\
\text { for water }\end{array}$} & $\begin{array}{c}\text { Tariff to } \\
\text { unit } \\
\text { cost } \\
\text { ratio }\end{array}$ & $\begin{array}{c}\text { Unit } \\
\text { cost } \\
\mathrm{US} \$ / \mathrm{m}^{3}\end{array}$ \\
\hline & 2005 & 2001 & 2005 & 2001 & 2005 & 2001 & 2002 & 2002 \\
\hline Lusaka & 77 & 56 & 75 & 73 & 56 & 58 & 81 & 0.31 \\
\hline $\begin{array}{l}\text { Former } \\
\text { AHC-MMS }\end{array}$ & 82 & 70 & 71 & 50 & 32 & 51 & 54 & 0.28 \\
\hline Mulonga & 58 & 34 & 59 & 48 & 61 & 57 & 108 & 0.13 \\
\hline Kafubu & 65 & 31 & 95 & 38 & 57 & 50 & 57 & 0.2 \\
\hline Nkana & 81 & 44 & 76 & 44 & 45 & 59 & 99 & 0.2 \\
\hline Southern & 57 & 51 & 65 & 78 & 56 & 52 & 81 & 0.21 \\
\hline Western & 76 & 68 & 61 & 53 & 44 & 67 & 123 & 0.08 \\
\hline Northwestern & 94 & 86 & 52 & 47 & 45 & 40 & 42 & 0.36 \\
\hline Chambeshi & 76 & - & 36 & - & 60 & - & - & - \\
\hline Chipata & 81 & 99 & 79 & 108 & 29 & 25 & 107 & 0.36 \\
\hline $\begin{array}{l}\text { Weighted } \\
\text { Average }\end{array}$ & 75 & 60 & 67 & - & 49 & 51 & - & - \\
\hline
\end{tabular}

Note:

a: Costs include cost of operations and maintenance.

Source: Own estimates based on data from NWASCO 2002, 2003 and 2005

The process of commercialization, however, did not start in 2000 but in the late 1980s with the commercialization of water supply services in Lusaka in 1989, tariff increases from 1992 onwards and a series of legal changes. In the 1980s, the government had already started searching for ways to improve financial performance in the water and sanitation sector. A major study was funded by the government, the World Bank and the UNDP and undertaken by a private consultancy firm, Coopers and Lybrand Co., to assess the issues in the water and sanitation sector and inform the government about the possible reform strategies. The study found that the revenues of urban suppliers covered 83 per cent of total operational and maintenance costs in 
1987 (Coopers and Lybrand, 1988). When this is compared to the average cost recovery of 67 per cent in 2005 (see Table 1) it becomes pertinent to ask what has gone wrong in the process of commercialization.

Apart from the fact that each water and sanitation company has a different cost structure, ${ }^{4}$ the failure to cover costs after the commercialization of water services and variations in performance can largely be explained by two factors. First, and perhaps most important, all existing providers suffer from high levels of unaccounted for water (UFW) that make cost recovery a mission impossible. UFW reflects the difference between the amount of water produced and the amount that is billed. Since 2001, the weighted average of UFW rates have remained around 50 per cent; in 1987, before commercialization started, this rate was around 28 per cent (Coopers and Lybrand, 1988).

With the exception of Chipata WSC, utilities that made some progress in this respect still have very high UFW rates (see Table 1). The most important causes of UFW are leakages in the system, due to lack of maintenance and poor infrastructure, and water wastage as a result of unmeasured consumption coupled with fixed payments. Sector specialists and company annual reports also mention vandalism, ineffective accounting and monitoring of customer databases as reasons for UFW (AHC-MMS, 2002, 2003; Nkana WSC, 2003). Given the variety of reasons for high UFW rates, the solutions have to involve a multi-faceted approach. However, the key to all solutions is investment, in repairs and maintenance, in renewing and extending the network, in metering, in systems of monitoring and in human resources.

Second, although the number of bills collected by the utilities since 2001 has increased, on average 25 per cent of the billed amount still remained uncollected in 2005 (Table 1). Some companies such as Mulonga and Western WSCs had high enough tariffs to cover the unit cost of supply, but were unable to break even because of uncollected bills. Non-payment by both residential customers and government institutions is a serious problem leading to high levels of arrears. Some companies disconnect domestic users with high arrears. ${ }^{5}$ In Lusaka, government institutions consumed around 50 per cent of the water supply as of 2005 but paid off only a small

\footnotetext{
${ }^{4}$ This is because physical conditions of water production, the state of infrastructure, wages and salaries, sanitation coverage etc. differ from one utility to another. For example, distance from the network and the source of water influence the energy costs of pumping. ${ }^{5}$ AHC-MMS, for example carried out 13721 disconnections during 2002-03 (AHC-MMS, 2003).
}

Development and Change, Vol. 39, Issue 1, January 2008 
proportion of their accumulated debt. The 'bad debt' provisions, which reflect the level of arrears in payments, amounted to 25-30 per cent of the collected revenues in the annual reports of Lusaka, AHC-MMS and Nkana in 2002. Problems in the administrative capacity of water and sanitation companies ${ }^{6}$ also contribute to low revenue collection.

Taking these two factors together implies that the water utilities earned revenues for only 37.5 per cent of their production on average in 2005, since half of the water they produced was not billed and a quarter of the billed amount was not collected.

\section{Affordability of Water Tariffs}

In Zambia, households have been charged for water according to the housing category they occupy. Families in low-cost housing pay less than those in medium and high-cost housing. Those who use public tap pay the least. Due to limited metering of domestic connections, most users pay a flat or fixed monthly rate, irrespective of the quantity of water they consume.

The commercialization of water tariffs started in the early 1990s. Between 1992 and 1994, the fixed charges for unmetered residential connections more than doubled for medium-cost housing and more than quadrupled for low and high-cost housing in real terms. ${ }^{7}$ The new tariffs soon became politically untenable and the government had to lower them. Since the mid 1990s, and especially after the establishment of new commercial utilities from 2000 onwards, there have been further adjustments to water tariffs.

Table 2. Increases in Monthly Water Charges for Selected Utilities (\%)

\begin{tabular}{|l|c|c|c|c|c|c|c|}
\hline \multicolumn{3}{|c|}{ Unmetered (1990-2006) } & \multicolumn{4}{l|}{ Metered (1992-2006) } \\
\hline & $\begin{array}{c}\text { Low-cost } \\
\text { housing }\end{array}$ & $\begin{array}{c}\text { Mid-cost } \\
\text { housing }\end{array}$ & $\begin{array}{c}\text { High cost } \\
\text { housing }\end{array}$ & & $6 \mathrm{~m}^{3}$ & $15 \mathrm{~m}^{3}$ & $30 \mathrm{~m}^{3}$ \\
\hline Lusaka & 461.7 & 289.6 & 831.2 & Lusaka & 153.7 & 610.2 & 880.8 \\
\hline
\end{tabular}

\footnotetext{
${ }^{6}$ For example, problems with creating and updating customer databases, developing effective payment systems, and following up on unpaid bills.

${ }^{7}$ The absolute values of water charges over time are given in Table A1 in the Appendix.

Development and Change, Vol. 39, Issue 1, January 2008
} 


\begin{tabular}{|l|c|c|c|c|c|c|r|}
\hline Nkana & 214.8 & 75.1 & 277.2 & Nkana & 153.7 & 572.2 & 869.5 \\
\hline Southern & 222.8 & 61.7 & 158.7 & Southern & 153.7 & 534.1 & 773.7 \\
\hline Western & 707.1 & - & 250.3 & Western & 153.7 & 591.2 & 910.4 \\
\hline
\end{tabular}

Source: Estimated using tariff data by Ministry of Energy and Water Development for the 1990s and by NWASCO for more recent years. Estimates are based on constant prices.

The increase in monthly water charges (in constant prices) for selected utilities is presented in Table 2. ${ }^{8}$ In comparison with 1990 (that is, prior to commercialization), the escalation in water charges in 2006 was much greater for the low-cost housing category than for the medium-cost category for all utilities, and greater than the highcost category for some utilities. Nkana WSC reduced water charges for medium and low-cost housing in 2006, after taking over the most financially viable company, AHC-MMS, which supplied the mines in the Copperbelt. Charges for metered connections have been much lower for small consumption (up to 15 cubic meters) than fixed charges for unmetered connections (see Appendix Table A1). In fact, having metered connections would have halved the water bill of the families in lowcost housing with a consumption of less than $15 \mathrm{~m}^{3}$ per month in 2002, and reduced it by between 20 and 66 per cent in 2006. This pricing strategy has been a means of revenue maximization for commercial utilities with the task of cost recovery, since a large proportion of the urban population occupy low-cost housing ${ }^{9}$ and most connections are not metered. ${ }^{10}$ In spite of the successive real increases, water charges applied by Zambian utilities are still the lowest in sub-Saharan Africa (Ballance and Tremolet, 2005). Yet, the affordability of current tariffs continues to be a problem.

In the literature, one of the most frequently used methods for assessing the affordability of water tariffs involves a benchmark ratio of household water expenditure to household income. The World Bank uses a benchmark set by the PanAmerican Health Organization, that households should spend no more than 5 per cent of their monthly income on water (World Bank, 2001). In the UK, the government considers water tariffs to be unaffordable if expenditure exceeds 3 per cent of household income, which is twice the current median spending ratio on water in the

\footnotetext{
${ }^{8}$ Lusaka and Nkana (after taking over AHC-MMS) are the largest water and sanitation companies in the country in terms of the water produced. Southern WSC is of medium size and Western WSC is one of the smallest utilities.

${ }^{9}$ According to Central Statistical Office (2004), around 80 per cent of the urban population lives in low-cost housing.

${ }^{10}$ According to NWASCO (2005), the metering rate is below 40 per cent for all water companies, except for Nkana and Chipata.
}

Development and Change, Vol. 39, Issue 1, January 2008 
country (Sawkins and Dickie, 2005). A recent Human Development Report (UNDP, 2006) also suggests that no household should spend more than 3 per cent of its income on water.

Although this method may appear rather arbitrary, it can be applied in countries where data limitations prevail, and the results often provide valuable insights. Other methods used in the literature, such as revealed or stated preferences approaches, which approximate 'willingness to pay', may seem more sophisticated but suffer from the same problems of subjectivity (Komives et al., 2005). In addition, they require more data than are usually available from national household surveys.

The estimates of affordability in this paper are therefore based on expenditureincome ratios. In Zambia, expenditure on water by households without meters is equal to the fixed monthly charges applied by water companies. Figures were obtained from the regulator, NWASCO, for seven different regional utilities. Monthly water charges for low-cost housing are used in the calculations, since around 80 per cent of the urban population live in low-cost housing. The calculations were carried out for three different household categories in the urban areas, with data obtained from the Central Statistical Office (2004):

a) households on different scales of income distribution

b) households in moderate poverty

c) households in extreme poverty. 
Table 3. Affordability of Water Tariffs by Urban Households (\%)

\begin{tabular}{|c|c|c|c|c|c|c|c|}
\hline \multirow{2}{*}{$\begin{array}{l}\text { Urban } \\
\text { Households } \\
\text { (HH) by income } \\
\text { decile } \\
\end{array}$} & \multicolumn{7}{|c|}{$\begin{array}{l}\text { Ratio of monthly water charges for low-cost housing to mean monthly household income in the urban } \\
\text { areas }\end{array}$} \\
\hline & Lusaka & $\begin{array}{l}\text { Mulonga, } \\
\text { Copperbelt }\end{array}$ & Western & $\begin{array}{l}\text { AHC-MMS, } \\
\text { Copperbelt }\end{array}$ & Southern & $\begin{array}{c}\text { Nkana, } \\
\text { Copperbelt }\end{array}$ & Chipata \\
\hline $\begin{array}{l}\text { 1st (lowest } \\
\text { income) }\end{array}$ & 29.8 & 31.6 & 36 & 36.7 & 14.1 & 21.1 & 56.2 \\
\hline 2nd & 13.6 & 14.4 & 16.4 & 16.7 & 6.4 & 9.6 & 25.6 \\
\hline 3rd & 9 & 9.5 & 10.8 & 11.1 & 4.2 & 6.4 & 16.9 \\
\hline 4th & 6.7 & 7.1 & 8.1 & $\begin{array}{l}8.3 \\
\end{array}$ & 3.2 & 4.8 & 12.7 \\
\hline 5th & 5.2 & 5.5 & 6.3 & 6.4 & 2.4 & 3.7 & 9.8 \\
\hline 6th & 4 & 4.3 & 4.9 & 5 & 1.9 & 2.8 & 7.6 \\
\hline 7th & 3 & 3.2 & 3.6 & 3.7 & 1.4 & 2.1 & 5.6 \\
\hline 8th & 2.2 & 2.3 & 2.7 & 2.7 & 1 & 1.6 & 4.2 \\
\hline 9th & 1.4 & 1.5 & 1.7 & 1.8 & 0.7 & 1 & 2.7 \\
\hline \multirow[t]{2}{*}{$\begin{array}{l}\text { 10th (highest } \\
\text { income) }\end{array}$} & 0.4 & 0.4 & 0.5 & 0.5 & 0.2 & 0.3 & 0.8 \\
\hline & \multicolumn{7}{|c|}{ Approximate proportion of the urban population for whom water is unaffordable ${ }^{a}$} \\
\hline $\begin{array}{l}\text { Using } 5 \% \\
\text { benchmark }\end{array}$ & 40 & 50 & 50 & 50 & 20 & 30 & 60 \\
\hline $\begin{array}{l}\text { Using 3\% } \\
\text { benchmark }\end{array}$ & 60 & 60 & 60 & 60 & 30 & 40 & 70 \\
\hline & \multicolumn{7}{|c|}{ Ratio of monthly water charges for low-cost housing to monthly mean household income for: } \\
\hline Extreme Poor & 7.4 & 7.9 & 9 & 9.2 & 3.5 & 5.3 & 14 \\
\hline Moderate Poor & 5.2 & 5.6 & 6.3 & 6.5 & 2.5 & 3.7 & 9.9 \\
\hline
\end{tabular}

Note:

a: These are rough estimates (approximations).

Source: Based on income distribution data from Central Statistical Office (2004). Fixed monthly low-cost water charges were obtained from NWASCO for 2002-03.

Development and Change, Vol. 39, Issue 1, January 2008 
The results are presented in Table 3. Thus, for instance, a fixed monthly low-cost water charge applied by Lusaka Water and Sanitation Company in 2002-03 constituted around 30 per cent of the average income of households in the first decile of income distribution (that is, those with the lowest incomes). In most urban centres, households at the lower end of the income distribution — up to the third decile spend some 10 per cent or more of their average monthly income on water, with the exception of households in the Southern province and to some extent in Nkana in the Copperbelt. The calculation of the proportion of households in each decile in which monthly spending on water exceeds a benchmark of 5 per cent or 3 per cent of their average income provides us with an estimate of the rate of affordability of low-cost water charges.

For example, using the 5 per cent benchmark, low-cost water charges in Lusaka were beyond the means of approximately 40 per cent of the urban population (the households in the first four deciles) in 2002-03. Using the 3 per cent benchmark yields an unaffordability rate of approximately 60 per cent. These estimates clearly show that affordability of even the lowest tariffs is a problem for urban households in Zambia. Overall, low cost tariffs constitute more than 5 per cent of household income for over 40 per cent of urban households, and more than 3 per cent of income for around 60-70 per cent of urban households, except for those in the Southern province and Nkana.

In the final part of Table 3, the affordability of low-cost water charges is estimated for households in extreme and moderate poverty, using the mean household income for each category. ${ }^{11}$ These figures reveal that low-cost monthly payments account for above 3 per cent of the average incomes of poor households in both categories, except for those in the Southern province. ${ }^{12}$ In comparison, the estimates for lower deciles appear much higher than those for extreme and moderate poverty. This reflects the wide disparities in the income levels of the poor.

\footnotetext{
${ }^{11}$ Extreme and moderate poverty lines are defined in Central Statistical Office (2004) as 64,530 and 92,185 kwacha per month per person, respectively.

${ }^{12}$ Note that poverty in general affects around 68 per cent of the population. Around 38 per cent of households are in extreme poverty (Central Statistical Office, 2004). In 2002, the mean monthly income was 228,331 and 323,483 kwacha for extremely and moderately poor households, respectively.
} 
Some caveats are in order here, to emphasize the fact that these estimates are far from being precise. First of all, low-cost housing may not always be occupied by poor households. Secondly, mean urban incomes in each decile in Table 3 reflect the Zambian average, but in some provinces (such as Lusaka and the Copperbelt) average urban household incomes are higher than the national average, while in others (such the Western and Eastern provinces) they are much lower. This may be considered a source of 'estimation-bias', leading to an over-estimation of the unaffordability rates for urban locations such as Lusaka and the Copperbelt. However, since around 80 per cent of the total population in each of these provinces is located in urban areas, and each province contains over one-third of the total urban population, urban income distribution data for Zambia is likely to be heavily influenced by the pattern of distribution in these provinces and a significant over-estimation of the rates of unaffordability is therefore unlikely.

The results in Table 3, albeit imprecise, are revealing about the number of people in urban areas who experience difficulties in meeting the expense of one of the most essential of human needs, water. The results are even more interesting in a regional perspective. Zambia has some of the lowest water charges in sub-Saharan Africa one reason why stakeholders in the water and sanitation sector push for further tariff rises. Hence, the Zambian case presents policy makers with a paradox. If the lowest water charges (those for low-cost housing) are unaffordable for a significant proportion of the population in Zambia, where average tariffs are already low in comparison to other countries in the region, it seems clear that the aspirations of cost recovery and extending access to water will not be achieved with the current strategy of reliance on tariff increases for generating funds for investment.

Metering may seem to offer a solution, since water charges for metered connections are lower for small users. This would not only lower the bills for households using up to $15 \mathrm{~m}^{3}$ of water per month, but also encourage all households to avoid wasteful use. Under the current system, price increases have no influence on the quantity of water used because most households are on fixed monthly tariffs. In other words, metering may also reduce the UFW levels. However, there are a number of factors that may reduce the feasibility and effectiveness of metering. First, interviews with sector specialists which were carried out during the fieldwork revealed that in some urban centres metering is not effective because water pressure is low and air in the pipes keeps meters running even when supply is interrupted. 
Second, the cost of a meter ${ }^{13}$ is quite high for poor households to meet, unless subsidized or paid for in installments. Finally, as the number of connections with meters increases over time, the utilities may change their current pricing strategy and charge higher tariffs for measured consumption, thus eroding the welfare gains from metering for small users.

\section{Access to Safe Water in Urban Areas}

In Zambia, access to piped water has always been the privilege of the urban population along the narrow line of the railway from Livingstone to the Copperbelt. Because of economic decline and reduced capital spending in the sector, not much improvement could be made on the initial rates of urban access to water inherited at independence. In fact, data from different sources indicate that there has been deterioration in the access rates following the commercialization of the services, with some differences in the scale of decline. For example, according to the World Bank (2006), the proportion of the Zambian population with access to safe water declined from 73 per cent in 1990, before the start of commercialization, to 53 per cent in 2005. According to the Zambia Demographic and Health Surveys (Central Statistical Office, various years), the fall in national access rates was slightly less, from 72.1 per cent in 1992 to 57 per cent in 2004. Prior to commercialization, urban population growth was much higher, so the fall in access rates is unlikely to be a reflection of an extraordinary increase in urban population. Rather, access rates have declined because of reduced capital spending in the sector, which will be discussed below. ${ }^{14}$

The decline in overall urban access rates has been much less pronounced, going down from 93 per cent in 1992 to 90 per cent in 2002, as shown on the right-hand side of Table 4a. What is interesting is that data from the Zambia Demographic and Health Surveys (Central Statistical Office, various years) indicate a significant deterioration in the 'quality of access' to water, as reflected by the proportion of the urban population who lost their access to residential pipes and became dependent on public taps, wells and boreholes (around 25 per cent). In 2002, almost 40 per cent of

\footnotetext{
${ }^{13}$ In 2004, the cost was equivalent to US\$ 90.

${ }^{14}$ The annual growth rate for the urban population was in the range of 6-8 per cent in the 1960s and 1970s, 3 per cent in the 1980s, and less than 2 per cent since the 1990s.
}

Development and Change, Vol. 39, Issue 1, January 2008 
the urban population was supplied by commercial utilities, close to 10 per cent by local authorities and another 20 per cent by NGOs. The rest of the urban population relied on sources such as wells, rivers and ponds (MLGH, 2004).

Table 4a. Access to Safe Water in Urban Areas (\% of urban population)

\begin{tabular}{|l|l|l|}
\hline & $\mathbf{1 9 9 2}$ & $\mathbf{2 0 0 2}$ \\
\hline Total Urban Access $^{\mathrm{a}}$ & 93 & 90.2 \\
\hline Piped into residence & 55 & 42 \\
\hline Public taps & 34 & 38 \\
\hline Wells and boreholes & 9 & 16 \\
\hline Rivers, ponds, lakes etc. & 2 & 4 \\
\hline
\end{tabular}

Note:

a: Excludes water from unprotected wells, rivers, springs, streams, ponds and lakes.

Source: Central Statistical Office (various years).

Table 4b. Access to Safe Water in Urban Areas from Commercial Utilities (\% of urban population)

\begin{tabular}{|l|c|c|}
\hline $\begin{array}{l}\text { Water Supply } \\
\text { Companies }\end{array}$ & $\begin{array}{c}\text { Access Rates } \\
\text { in 2005 }\end{array}$ & $\begin{array}{c}\text { Change in Access } \\
\text { Rates 2001-05 (\%) }\end{array}$ \\
\hline Lusaka & 79 & 13 \\
\hline $\begin{array}{l}\text { Copperbelt, former AHC- } \\
\text { MMS (Mines) }\end{array}$ & 92 & -4 \\
\hline Copperbelt, Nkana & 62 & 33 \\
\hline Copperbelt, Mulonga & 86 & -5.5 \\
\hline Copperbelt, Kafubu & 93 & 11 \\
\hline Southern & 63 & 17 \\
\hline Western & 47 & -57 \\
\hline Northwestern & 15 & -52 \\
\hline Chambeshi & 39 & n.a. \\
\hline Chipata & 69 & -2.8 \\
\hline Weighted Average & 58 & -21 \\
\hline
\end{tabular}

Source: NWASCO (2005).

The water supply and sanitation companies supplied on average 58 per cent of the population in their service area in 2005 (Table 4b). Access to water has been reasonably good and considerably above the average in the Copperbelt and Lusaka regions but not in other provinces. None of these utilities provide 24 hour continuous supply: the average daily flow of water was 16 hours in 2005 for medium and large 
towns. Despite variations in the coverage of the population by different suppliers, the utility data clearly show that the process of commercialization not only failed to reverse the negative trend in access rates, but that access rates have declined by an average of more than 20 per cent since 2001.

In Zambia, a considerable proportion of the urban population lives in unplanned settlements, or the so-called peri-urban areas. Water supply in these areas is a serious problem due to the well-known complexities associated with absence of legal titles to the land occupied by the households (Komives et al., 2005; UNDP, 2006). Most households in these areas depend on boreholes, communal or public taps built by commercial utilities, NGOs and donors. Various arrangements exist for the operation of such schemes: some are managed solely by communities, some are managed by communities in co-operation with public utilities and others are run by vendors (Dagdeviren, 2007). The small size of these schemes reduces the cost effectiveness of operations. Cash collection at water supply points is often problematic (World Bank, 2003).

The commercial suppliers in the formal sector are reluctant to provide water in these areas because the financial returns are negligible, while the independent supply systems set up by NGOs and donors suffer from serious capacity and management problems. Communities lack the capacity to deal with breakdowns and other sorts of supply failures. Public utilities are often brought in to tackle such problems. In Lusaka, for example, there are over thirty informal settlement areas, known locally as 'compounds', where around 50 per cent of the capital's population live. Half of the population in the compounds is served by Lusaka Water and Sanitation Company, mostly by public taps and to a lesser extent by individual yard taps. Lusaka WSC also reluctantly manages a number of water supply systems installed by NGOs. George Complex, for example, is one of the biggest compounds; here the water supply system has been provided by Japan International Cooperation Agency (JICA). Lusaka WSC is the manager of the water supply services in the compound and responsible for the collection of bills and maintenance (Dagdeviren, 2007).

The quality of water in peri-urban areas is known to be poor. Ground water contamination through lack of proper sanitation facilities is part of the problem. Water supply in these areas is limited, often a few hours each in the morning and in the afternoon. There are also limits on the amount of water households can draw every day. Depending on the supply arrangement, a fixed fee is paid on either a daily

Development and Change, Vol. 39, Issue 1, January 2008 
or a monthly basis. According to the World Bank (2002), some poorer households do not participate in water supply systems in the compounds but share the water cards of participating households, while others accumulate arrears or find sources of illegal supply.

Access and water supply problems in peri-urban areas are currently receiving considerable attention because of the agenda set by the Millennium Development Goals (MDGs). The response of the regulatory agency, NWASCO, to the MDG for water is to promote access in peri-urban areas through 'water kiosks' that are run by individual operators for a commission and maintained by the commercial utilities (NWASCO and DTF, 2005). This strategy is advocated for its feasibility in the medium term, as water kiosks involve low-cost technology and provide for an affordable service. The results are yet to be seen. While the urgency for access to safe water in unplanned settlements and the impetus given by the MDGs justifies such low-cost interventions, there are a number of reasons to be cautious. The kiosk concept is not radically different from existing systems, such as communal taps, whose commercial viability has been problematic. NWASCO recognizes this and suggests that the operators should be permitted to undertake other commercial activities at kiosks to supplement their income. It is not clear who would shoulder the cost of maintenance: commercial utilities, operators or users? The answer to this question has further implications for the viability of this option in the long-term.

\section{TO INVEST OR NOT TO INVEST: A RE-ASSESSMENT}

The literature on utility services provides ample evidence of the importance of investment for the performance of utility companies, the efficiency of their operations and the future security of supply in meeting increasing demand for basic services. For the power sector, Hirschhausen et al. (2004), Neuho and de Vries (2004), and Woo et al. (2003) all highlight the inadequacies of market-based solutions in maintaining required investments and adequate levels of production capacity. Chisari et al. (2003) note that even with regulation and related pricing systems (price caps or cost-plus approaches) there is often too little or too much investment. Hence, he stresses the importance of 'planning' for the current and future security of supply of utility services. Evidence from the water sector similarly shows that the lack of adequate 
investment makes a crucial difference in performance (Alcazar et al., 2002; Beddies et al., 2004; Shaoul, 1997).

Public sector utilities can be efficient in many respects (affordability, high revenue generation, cost recovery, service reliability, resource conservation) as long as they involve sufficient levels of investment with long-term planning. This point has been amply demonstrated by successful public utilities such as NamWater in Namibia and ONEA in Burkina Faso (Bayliss, 2003); EMOS in Santiago, Chile (Shirley et al., 2002); public water suppliers in Korca, Albania (Beddies et al., 2004); ESCOM in South Africa and NamPower in Namibia (Eberhardt et al., 2005).

In Zambia, one of the important reasons behind the commercialization process's failure to turn its stated objectives into reality is that it has become a means for the government to relinquish its responsibility for investment in the sector. Lack of investment during the fiscal austerity of the 1980s continued into the 1990s when, under the pretext of commercialization, government transfers to the water sector for investment were almost entirely eliminated (NWASCO, 2003).

Much of the existing water infrastructure in Zambia was built in the 1970s. The donor grants or loans provided to some water and sanitation companies at the start of the commercialization process were not sufficient to fully rehabilitate the existing networks, except for Chipata where investments were funded by the German technical development organization, GTZ. This explains why Chipata had the lowest UFW (26 per cent) and the highest cost coverage rate (91 per cent) in the sector in 2006 (NWASCO, 2006). Lack of investment in the sector has serious implications for the future sustainability of services. The Lusaka WSC, for example, has made no major investment in recent years. It had a water production capacity of 220 million litres per day in 2002, far below the estimated 300 million litres per day aggregate demand for water that year. The water network is more than thirty years old (Lusaka WSC, 2002) and some pipes in the city's sewer network are more than forty years old (PANA, 2004).

The Water Supply and Sanitation Development Group prepared a medium-term development strategy for the government to implement during 1994-2003. Their estimations suggested that the government had to invest between US\$ 407 million (a low-cost investment strategy) and US\$ 1,553 million (a medium-cost investment strategy) every year during this period in order to rehabilitate the existing system and expand the network to avoid any reduction in access rates. In other words, the Development and Change, Vol. 39, Issue 1, January 2008 
government did not plan to extend access to safe water in Zambia in this period, but it did aim to maintain the existing infrastructure and population coverage.

Table 5. Expenditure in Water and Sanitation Sector, 1998-2002

\begin{tabular}{|c|c|c|c|c|c|c|}
\hline & \multicolumn{3}{|c|}{ Government Capital Expenditure } & \multirow{2}{*}{$\begin{array}{c}\text { Total } \\
\text { Spending by } \\
\text { Donors and } \\
\text { NGOs (US\$ } \\
\text { million) } \\
\end{array}$} & \multicolumn{2}{|c|}{$\begin{array}{l}\text { Actual expenditure as \% of } \\
\text { required capital expenditure }\end{array}$} \\
\hline & $\begin{array}{l}\text { Budget } \\
\text { (B) US\$ } \\
\text { million }\end{array}$ & $\begin{array}{l}\text { Actual } \\
\text { (A) US\$ } \\
\text { million }\end{array}$ & $\begin{array}{l}\mathrm{A} / \mathrm{B} \\
(\%)\end{array}$ & & $\begin{array}{l}\text { Low cost } \\
\text { scenario }\end{array}$ & $\begin{array}{l}\text { Medium cost } \\
\text { scenario }\end{array}$ \\
\hline 1998 & 12.1 & 0.4 & 3.1 & 36 & 8.9 & 2.4 \\
\hline 1999 & 7.4 & 0.2 & 2.4 & 45 & 11 & 2.9 \\
\hline 2000 & 3.4 & 0.1 & 3 & 28 & 6.9 & 1.8 \\
\hline 2001 & 3.5 & 0.4 & 12.3 & 31 & 7.7 & 2 \\
\hline 2002 & 6.1 & 0.5 & 8.8 & 33 & 8.2 & 2.2 \\
\hline
\end{tabular}

Note:

a: Capital expenditure required to rehabilitate existing facilities and network, and to expand the network to avoid any reduction in the access rate. Actual expenditure is the sum of capital expenditure by the government and total expenditure by the donors and NGOs.

Source: Estimated using data from Ministry of Local Government and Housing (2004).

In reality, capital spending in the water and sanitation sector by the government during this period represented a small fraction of the required investments, as shown in Table 5. In 1987, the government had invested US\$ 16.6 million in the sector (MoD, 1988), thirty times more than the amount spent in 2002. From 1998 to 2002, the government invested between 2 and 12 per cent of its budgeted capital spending for the water and sanitation sector. NGOs and donors spent between US\$ 30 million and US\$ 45 million in total during the same time period. ${ }^{15}$ Even if we assume that all spending by donors and NGOs went into capital formation in the sector (which is unlikely) and add this amount to the actual capital spending undertaken by the government, the total sums come nowhere near to the required annual investments as shown in Table 5.

Government funding of capital expenditure in both the rural and urban water supply systems was US\$ 0.63 million in 2004. At this rate, the MDG for water is unlikely to be achieved in Zambia because even the most modest estimates based on

\footnotetext{
${ }^{15}$ Note that the investments undertaken by the commercial utilities were funded either by donors or the government. Investments by local authority suppliers (if any are undertaken), are funded by the government.
} 
quick fix solutions, such as the extension of water supply coverage through communal taps (especially kiosks), suggest that around Euros 20 million is needed to meet the MDG target for water (NWASCO and DTF, 2005).

All utilities in urban Zambia now require further increases in tariffs to enhance their performance and services. A superficial analysis might suggest that higher prices would boost their revenues and help them to invest more. But higher tariffs do not necessarily mean higher revenues: in Zambia, prior to corporatization and commercialization, the local authority suppliers were able to cover a higher proportion of their operational and maintenance costs on the basis of much lower tariffs than have been applied by the current utilities. Other studies have revealed similar findings (Roe et al., 2003; World Bank, 2003).

Given the evidence on declining access to water and the unaffordability of low water tariffs for a considerable portion of urban households, the commercialization of water services seems destined to be a failure without up-front investment. Investments in repairs, maintenance and network extension are likely to cut down the costs of production and distribution significantly through reduced UFW rates, which stood at around 50 per cent of the total water produced on average in the urban sector in 2005 (see Table 1). Notwithstanding the need to reduce the amount of water wasted by residential users, an important cause of high UFW levels is the poor state of infrastructure, which is likely to be putting upward pressure on unit production costs. Expansion of the network through new investments can also lower the average cost of production and improve the access of the population to safe water.

The ultimate question is how to finance investment in the water sector. Although this question requires further research, the discussion so far points to the funds raised by the public sector (both national and international) as the prime source for financing investment in low-income economies. The evidence in high income economies supports this view. For example, OECD countries provide substantial grants for financing capital expenditure in the water sector. In some cases, the public sector provides the full funding for such expenditure (Komives et al., 2005). In France, the government fund one-third of the capital expenditure of the private water companies (Dore et al., 2004). Taking account of the scale of funds required for service extension and maintenance, and the revenue limitations of low-income country governments, development assistance by donor countries has to be an important source of funding. 


\section{CONCLUSIONS}

Management and operation of water and sanitation services in the developing world are increasingly being commercialized. While reforms for improving service provision are welcome, it is important to focus on the compatibility of the means and ends in the process of implementation. The objective of achieving cost recovery in the provision of water supply services can be a means to increase the proportion of the population with access to safe water. With an inappropriate policy mix, the aspirations for cost recovery can also lead to the opposite result of declining access rates.

In general, reforms can target progress in three areas. The first involves reducing operational inefficiencies, for example by changing systems of management and organizational structure, reducing overstaffing, improving billing and revenue collection. The second entails addressing investment needs in the sector to reduce the cost of production and distribution through improved use of economies of scale and reduced UFW. The third requires increasing the tariff levels and changing the pricing structure to generate more revenue. In determining the composition of reforms, household incomes, poverty levels and the scale of investment needed in infrastructure should all be taken into account.

In Zambia, tariff increases have been at the centre of the commercialization process for cost recovery. Cuts in capital expenditure and measures to improve operational efficiency have also been part of the process. The reforms have been ineffective and the outcomes rather disappointing in some important areas. Despite the variation in performance across the ten commercial utilities, most are still far from achieving cost recovery. Their tariffs are low but nonetheless unaffordable to the majority. Quality of access to safe water in the urban sector has declined since the beginning of commercialization; more households now rely on public taps, boreholes and wells rather than water supply through residential pipes.

The strategy of getting prices right to achieve cost recovery (when the costs are already inflated due to poor infrastructure and the small size of the network) and improve the water network has been tried with little success. It is now time for upfront public investment in the extension of the network and renewal of the 
infrastructure to reach cost recovery in the sector, with affordable tariffs through reductions in unit costs and levels of unaccounted for water. Without this, there seems little chance of breaking out of the cycle of low investment, weak infrastructure, poor revenue collection and low levels of access to water and sanitation services.

\section{APPENDIX}

Table A1. Monthly Residential Water Tariffs (Kwacha, constant prices)

\begin{tabular}{|c|c|c|c|c|c|c|}
\hline & \multicolumn{3}{|c|}{$\begin{array}{l}\text { Fixed tariffs for unmetered } \\
\text { connections by housing category }\end{array}$} & \multicolumn{3}{|c|}{$\begin{array}{l}\text { Tariffs for metered } \\
\text { connections for: }\end{array}$} \\
\hline & $\begin{array}{l}\text { Low } \\
\text { cost }\end{array}$ & Medium cost & High cost & $\begin{array}{l}6 \mathrm{~m}^{3} \\
\text { water }\end{array}$ & $\begin{array}{l}15 \mathrm{~m}^{3} \\
\text { water }\end{array}$ & $\begin{array}{l}30 \mathrm{~m}^{3} \\
\text { water }\end{array}$ \\
\hline 1990 & 22.0 & 65.9 & 65.9 & $\begin{array}{l}- \\
-\end{array}$ & $\begin{array}{l}- \\
-\end{array}$ & - \\
\hline 1992 & 83.7 & 125.5 & 167.4 & 8.4 & 8.4 & 12.6 \\
\hline 1994 & 95.5 & $10 \% .1$ & 300.9 & - & - & - \\
\hline \multicolumn{7}{|c|}{ Tariffs of Selected Commercial Utilities in 2002} \\
\hline Lusaka & 114.3 & 183.0 & 643.7 & 16.2 & 45.3 & 93.8 \\
\hline $\begin{array}{l}\text { AHC- } \\
\text { MMS }^{\text {a }}\end{array}$ & 140.8 & 226.4 & 303.1 & 18.6 & 59.8 & 142.7 \\
\hline Nkana & 80.9 & 134.8 & 242.6 & 20.2 & 50.5 & 121.3 \\
\hline Southern & 53.9 & 80.9 & 141.5 & 18.2 & 60.6 & 158.4 \\
\hline Western & 138.1 & 239.2 & 239.2 & 57.3 & 57.3 & 113.9 \\
\hline \multicolumn{7}{|c|}{ Tariffs of Selected Commercial Utilities in 2006} \\
\hline Lusaka & 123.6 & 256.7 & 613.6 & 21.3 & 59.7 & 123.6 \\
\hline Nkana $^{\mathrm{a}}$ & 69.2 & 115.4 & 248.6 & 21.3 & 56.5 & 122.2 \\
\hline Southern & 71.0 & 106.5 & 170.5 & 21.3 & 53.3 & 110.1 \\
\hline Western & 177.6 & - & 230.8 & 21.3 & 58.1 & 127.3 \\
\hline
\end{tabular}

Note:

a: The management contract of AHC-MMS was terminated in 2005 and the utility was taken over by Nkana WSC.

Sources: Tariff data for the 1990s from Ministry of Energy and Water Development; data for 2002 and 2006 from NWASCO. Figures are deflated by CPI index. 


\section{REFERENCES}

AHC-MMS (2002) ‘Annual Report’. Kitwe: Asset Holdings Company-Mining Municipal Services.

AHC-MMS (2003) ‘Annual Report’. Kitwe: Asset Holdings Company-Mining Municipal Services.

Alcazar, L., M.A. Abdala and M. Shirley (2002) 'The Buenos Aires Water

Concession', in M.M. Shirley (ed.) Thirsting for Efficiency, pp. 65-102. Washington, DC: The World Bank.

Ballance, T. and S. Tremolet (2005) 'Private Sector Participation in Urban Water Supply in Sub-Saharan Africa'. Frankfurt: German Development Cooperation (GTZ), KfW Bankengruppe.

Bayliss, K. (2003) 'Utility Privatisation in Sub-Saharan Africa: A Case Study of Water', Journal of Modern African Studies 41(4): 507-31.

Beddies, S., H. De Soto, A. Bakllamja and X. de Beauchene (2004) Decentralization and Water Sector Privatization in Albania, Poverty and Social Impact Analysis.

Tirana, Albania: The World Bank/UNDP.

Central Statistical Office (various years) Zambia Demographic and Health Survey.

Lusaka: Central Statistical Office.

Central Statistical Office (2004) Zambia Living Conditions Monitoring Survey 20023. Lusaka: Central Statistical Office.

Chisari, O., A. Estache and C.W. Price (2003) 'Access by the Poor in Latin America's Utility Reform: Subsidies and Service Obligations', in C. Ugaz and C.W. Price (eds) Utility Privatization and Regulation, pp. 25-53. Cheltenham, UK: Edward Elgar.

Development and Change, Vol. 39, Issue 1, January 2008 
Coopers and Lybrand Co. (1988) 'Re-organization Study of the Water and Sanitation Sector in Zambia'. Final Report. Sponsored by the Government of the Republic of Zambia, the United Nations Development Programme and the World Bank. Lusaka: Government of the Republic of Zambia.

Dagdeviren, H. (2006) 'Re-visiting Privatization in the Context of Poverty Alleviation: The Case of Sudan', Journal of International Development 18(3): 46989.

Dagdeviren, H. (2007) 'Zambia: The Commercialisation of Urban Water and Sanitation', in K. Bayliss and B. Fine (eds) Privatization and Alternative Public Sector Reform in Sub-Saharan Africa: Delivering on Electricity and Water, pp. 183-209. London: Palgrave Macmillan.

Dore, M.H.I., J. Kushner and K. Zumer (2004) 'Privatization of Water in the UK and France: What Can we Learn?’, Utilities Policy 12: 41-50.

Eberhardt, A., A. Clark, N. Wamukonya and K. Gratwick (2005) 'Power Sector Reform in Africa: Assessing Impact on Poor People'. Report by Energy Sector Management Assistance Programme, No 306/05. Washington, DC: The World Bank.

Estache, A., S. Perelman and L. Trujillo (2005) 'Infrastructure Performance and Reform in Developing and Transition Economies: Evidence from a Survey of Productivity Measures’. Policy Research Working Paper 3514 (February).

Washington, DC: The World Bank.

Hall, D. and E. Lobina (2004) 'Private and Public Interests in Water and Energy', Natural Resources Forum 28: 268-77.

Harris, C. (2003) 'Private Participation in Infrastructure in Developing Countries'. Working Paper No 5. Washington, DC: The World Bank. 
Hirschhausen, C., T. Beckers and A. Brenck (2004) 'Infrastructure Regulation and Investment for the Long Term: An Introduction', Utilities Policy 12: 203-10.

Kessides, I.N. (2004) Reforming Infrastructure: Privatization, Regulation, and Competition. Oxford and New York: Oxford University Press for the World Bank.

Kirkpatrick, C. and D. Parker (2006) 'Domestic Regulation and the WTO: The Case of Water Services in Developing Countries', World Economy 28(10): 1491-1508.

Kirkpatrick, C., D. Parker and Yin-Fang Zhang (2006) 'An Empirical Analysis of State and Private-Sector Provision of Water Services in Africa', The World Bank Economic Review 20(1): 143-63.

Komives, K., V. Foster, J. Halpern and Q. Wodon (2005) Water, Electricity, and the Poor: Who Benefits from Utility Subsidies? Washington, DC: The World Bank.

Lobina, E. (2005) 'Problems with Private Water Concessions: A Review of Experiences and Analysis of Dynamics’, Water Resources Development 21(1): 5587.

Lusaka WSC (2002) ‘Annual Report’. Lusaka: Lusaka WSC.

Martimort, D. (2006) 'An Agency Perspective on the Costs and Benefits of Privatization', Journal of Regulatory Economics 30: 5-44.

McDonald, D.A. (2002) 'The Theory and Practice of Cost Recovery in South Africa', in D.A. McDonald and J. Pape (eds) Cost Recovery and the Crisis of Service Delivery in South Africa, pp. 17-40. London: Zed Books; Cape Town: HSRC Publishers.

MoD (1988) 'Reorganization Study of the Water and Sanitation Sector in Zambia'. Final Report Vol.1. Lusaka: Ministry of Decentralization. 
MLGH (2004) 'Water Supply and Sanitation Sector Finance and Resource Flow

Assessment’. MLGH Sector Finance Working Paper No 7. Lusaka: Ministry of Local Government and Housing.

Neuho, K. and L. de Vries (2004) 'Insufficient Incentives for Investment in Electricity Generation’, Utilities Policy 12: 253-67.

Nkana WSC (2003) ‘Strategic Plan: 2003-2007’. Kitwe. Nkana WSC.

NWASCO (2002) 'Urban and Peri-Urban Water Supply and Sanitation Sector Report 2001/2002’. Lusaka: National Water Supply and Sanitation Council.

NWASCO (2003) 'Urban and Peri-Urban Water Supply and Sanitation Sector Report 2002/2003'. Lusaka: National Water Supply and Sanitation Council.

NWASCO (2004) 'Water Sector Reform in Zambia’. Report. Lusaka: National Water Supply and Sanitation Council.

NWASCO (2005) 'Urban and Peri-Urban Water Supply and Sanitation Sector Report 2004/2005’. Lusaka: National Water Supply and Sanitation Council.

NWASCO (2006) 'Urban and Peri-Urban Water Supply and Sanitation Sector Report 2005/2006’. Lusaka: National Water Supply and Sanitation Council.

NWASCO and DTF (2005) 'Reaching the Millenium Development Goals for Water Supply and Sanitation in Zambia'. Lusaka: National Water Supply and Sanitation Council and Devolution Trust Fund.

PANA (2004) 'Lusaka in Sewerage Disposal Nightmare’, Daily Newswire 24 November (Panafrican News Agency).

Prasad, N. (2006) 'Privatization Results: Private Sector Participation in Water Services after 15 Years’, Development Policy Review 24(6): 669-92. 
Roe, A., A. Feltham, A. Darbinyan, R. Yeganyan, N. Shakhnazaryan, L. Melikyan and A. Kakosyan (2003) 'Water Sector Reform in Armenia: Poverty and Social Impact Analysis'. Report for DFID (UK). London: Department for International Development.

Sawkins, J.W. and V.A. Dickie (2005) 'Affordability of Household Water and Sewerage Services in Great Britain’, Fiscal Studies 26(2): 225-44.

Shaoul, J. (1997) 'The Power of Accounting: Reflecting on Water Privatization’, Accounting, Auditing and Accountability Journal 10(3): 382-405.

Shirley, M.M., L.C. Xu and A.M. Zuluaga (2002) 'Reforming Urban Water Supply: The Case of Chile', in M.M. Shirley (ed.) Thirsting for Efficiency, pp. 189-231. Washington, DC: The World Bank.

Shirley, M.M. (ed.) (2002) Thirsting for Efficiency. Washington, DC: The World Bank.

Smith, L. (2006) 'Neither Public Nor Private: Unpacking the Johannesburg Water Corporatization Model'. Social Policy and Development Programme Paper No 27. Geneva: United Nations Research Institute for Social Development.

UNDP (2006) Human Development Report 2006. Beyond Scarcity: Power, Poverty and the Global Water Crisis. London: Palgrave Macmillan for United Nations Development Programme.

Ugaz, C. and C.W. Price (eds) (2003) Utility Privatization and Regulation. Cheltenham, UK: Edward Elgar.

Woo, C-K., D. Lloyd and A. Tishler (2003) 'Electricity Market Reform Failures: UK, Norway, Alberta and California’, Energy Policy 31: 1103-15.

World Bank (2001) 'Incentive-Based Subsidies’. Public Policy for the Private Sector, Note No 232. Washington, DC: The World Bank.

Development and Change, Vol. 39, Issue 1, January 2008 
World Bank (2002) ‘Upgrading Low Income Urban Settlements: Zambia Country Assesment Report'. Washington, DC: The World Bank.

World Bank (2003) 'Issues Facing Zambia’s Commerical Water Utilities: A Review Based on Studies from Copperbelt Province'. Washington, DC: The World Bank (mimeo).

World Bank (2004) 'Institutional Capacity Building for the Water Regulator: The National Water and Sanitation Council (NWASCO)'. (March). Washington, DC: The World Bank.

World Bank (2005) World Development Indicators. Online Database. http://devdata.worldbank.org/wdi2005/Cover.htm

World Bank (2006) 'Water Sector Performance Improvement Project’. Project Information Document (PID) Appraisal Stage, Report No AB441. Washington, DC: The World Bank. [Online Acess: http://wwwwds.worldbank.org/external/default/WDSContentServer/IW3P/IB/2006/05/02/00010 4615_20060502155219/Rendered/PDF/ZAM.WSPIP.FinalPID.pdf]

Hulya Dagdeviren is a reader in economics at the University of Hertfordshire, College Lane, Hatfield, Herts AL10 9AB, UK (e-mail: h.dagdeviren@herts.ac.uk). She has been consultant to various development organizations including the United Nations Development Programme. She has researched and published on poverty and inequality; privatization; utility sector reforms, especially of water and power; and on developing country indebtedness. 